\title{
Adaptation of the Recent Life Changes Questionnaire (RLCQ) to measure stressful life events in adults residing in an urban megapolis in Pakistan
}

Azmina Artani ${ }^{1 \dagger}$, Shireen Shehzad Bhamani ${ }^{2}$, lqbal Azam ${ }^{3}$, Moiz AbdulSultan ${ }^{4}$, Adeel Khoja ${ }^{1}$ and Ayeesha K. Kamal $\left.\right|^{5,6^{*}+}$

\begin{abstract}
Background: Contextually relevant stressful life events are integral to the quantification of stress. None such measures have been adapted for the Pakistani population.

Methods: The RLCQ developed by Richard Rahe measures stress of an individual through recording the experience of life changing events. We used qualitative methodology in order to identify contextually relevant stressors in an open ended format, using serial in-depth interviews until thematic saturation of reported stressful life events was achieved. In our next phase of adaptation, our objective was to scale each item on the questionnaire, so as to weigh each of these identified events, in terms of severity of stress. This scaling exercise was performed on 200 random participants residing in the four communities of Karachi namely Kharadar, Dhorajee, Gulshan and Garden. For analysis of the scaled tool, exploratory factor analysis was used to inform structuring. Finally, to complete the process of adaption, content and face validity exercises were performed. Content validity by subject expert review and face validity was performed by translation and back translation of the adapted RLCQ. This yielded our final adapted tool.

Results: Stressful life events emerging from the qualitative phase of the study reflect daily life stressors arising from the unstable socio-political environment. Some such events were public harassment, robbery/theft, missed life opportunities due to nepotism, extortion and threats, being a victim of state sponsored brutality, lack of electricity, water, sanitation, fuel, destruction due to natural disasters and direct or media based exposure to suicide bombing in the city. Personal or societal based relevant stressors included male child preference, having an unmarried middle aged daughter, lack of empowerment and respect reported by females. The finally adapted RLCQ incorporated "Environmental Stress" as a new category.
\end{abstract}

Conclusion: The processes of qualitative methodology, in depth interview, community based scaling and face and content validity yielded an adapted RLCQ that represents contextually relevant life stress for adults residing in urban Pakistan.

Trial registration: Clinicaltrials.gov NCT02356263. Registered January 28, 2015. (Observational Study Only).

Keywords: Recent life changes questionnaire, Adaptation, Pakistan

\footnotetext{
* Correspondence: ayeesha.kamal@aku.edu

${ }^{\dagger}$ Equal contributors

${ }^{5}$ Stroke Service, Department of Medicine, Aga Khan University, Karachi, Pakistan

${ }^{6}$ Section of Neurology, Department of Medicine, Stroke Fellowship Program, International Cerebrovascular Translational Clinical Research Training Program, Fogarty International Center, National Institute of Neurologic Disorders and Stroke (USA), Aga Khan University, Stadium Road, Karachi 74800, Pakistan Full list of author information is available at the end of the article
} 


\section{Background}

Stress is defined as the loss of equipoise between evolving changes in an individual's life and their capacity to adapt [1]. Although stress is a common phenomenon, its extent varies among people based on their perceptions and availability of appropriate coping strategies [2].

Assessing the burden of stress is not an easy task due to its subjectivity. As stress translates into many common mental disorders, the prevalence of mental disorders can serve as a relatively accurate measure for evaluating the effects of stress. Chronic stress may ultimately become the tipping point of common mental disorders such as depression, anxiety, mood disorders and suicide [3].

The Global Burden of Disease Survey conducted by World Health Organization (WHO) reports psychiatric illnesses along with stress-related disorders to be the second leading cause of disabilities by the year 2020 [4]. In 2010, depressive disorders had affected $40 \%$ of world's population [5]. In Pakistan, studies from both rural and urban areas report prevalence of depression from $3.4 \%$ to $40 \%[6,7]$.

Studies from Pakistan have reported tools that have been developed or adapted, translated and validated to measure stress [8]. These tools have been constructed for a specific condition e.g. anxiety or depression or for specific population for e.g. antenatal clinics, in-patient and out-patient psychiatric settings, adolescents and teachers (Table 1) [8-16]. There is a need for a generalizable tool to be used in community settings that can measure stress in the general population.

An important mediator of stress is the occurrence of repeated Stressful Life Events in the domains of home, health, work, environment and personal and social life. Rahe and Holmes developed a tool using these events so as to measure stress which is known as "Social Readjustment and Rating Scale (SRRS)". However, SRRS had a limited item range which was reviewed periodically by these researchers and led to the development of another tool namely "Recent Life Changes Questionnaire (RLCQ)" in 1997 [17, 18]. RLCQ measures stress through life changing events occurring during a specified time frame (6 months or a year) and measures its consequences on health of an individual.

Pakistan is a developing country where daily life stressors have a major influence on mental health of people and no tools are available that measure stress in the general population in a relevant and contextually appropriate fashion. Hence, the aim of this study is to report the process of adaptation of the RLCQ with respect to the general population of urban Pakistan where the adapted tool becomes accurate and relevant.

\section{Methods}

\section{Study design and setting}

The study incorporated qualitative methodology following COREQ guidelines [19]. First, it followed a phenomenology study design as we aimed to explore stressors relevant to Pakistani context. We conducted serial in-depth interviews along with translating the tool and seeking expert's opinion [19]. This was followed by community based scoring of each stressful item on the adapted tool (Fig. 1).

Karachi best represents the multi-ethnicity of Pakistan due to its metropolitan nature and extreme diversity and thus was the ideal site for this study for reasons of external validity.

\section{Populations for in-depth interviews and rating}

Participants were recruited from the outpatient departments of Aga Khan University, Hospital (AKUH) which serves people from diverse socio-cultural backgrounds who visit for regular health checkups e.g. vaccination, eye checkups, employee assessment. They were invited and consented for in-depth interviews for theme identification of stressors that may not have been listed in the original RLCQ due to cultural differences.

Following these open ended in-depth interviews and theme identification, we proceeded to community scaling. From February to March 2015, we recruited adult participants from four communities in Karachi namely Kharadar, Dhorajee, Gulshan and Garden. These communities represent the various ethnic groups within Pakistan and ensure a better generalization (Fig. 2). Those who could understand Urdu and were willing to participate were invited to be part of the study however; individuals who had been taking medications prescribed for existing mental conditions were excluded because the use of medication may have altered their perception of severity of daily life stressors. These communities helped rate the scale of stressful life events that were identified in the open ended qualitative part of the study.

\section{Study procedures \\ Step I: In-depth interviews and adaptation steps}

Qualitative interviews began in December 2014 from men and women aged $\geq 18$ years who were able to understand Urdu and provided written informed consent. We excluded those participants who had cognitive, hearing or speech difficulties due to strokes or other organic impairments. There was no direct personal relationship with the participants prior to study commencement. However, the community trusts and has a good relationship with the institution. The purpose of these interviews was to explore the understanding of stress and to gain insight into stressful life events at the 
Table 1 Validated Stress Measurement Scales in Pakistan

\begin{tabular}{|c|c|c|c|c|c|}
\hline Scale & Purpose & Validated against & $\begin{array}{l}\text { Year (sample size) } \\
\text { site }\end{array}$ & Strength & Population \\
\hline $\begin{array}{l}\text { General Health } \\
\text { Questionnaire } \\
\text { [GHQ-28] [1] }\end{array}$ & $\begin{array}{l}\text { Translation and } \\
\text { Validation }\end{array}$ & $\begin{array}{l}\text { Hospital Anxiety } \\
\text { and Depression } \\
\text { Scale (HADS) by } \\
\text { Zigmond (1983) }\end{array}$ & $\begin{array}{l}1998(162) \\
\text { Karachi }\end{array}$ & $\begin{array}{l}\text { Correlation } \\
\text { coefficient } r=0.62 \\
\text { Cronbach's } \\
a=0.90\end{array}$ & $\begin{array}{l}\text { Medical and } \\
\text { nursing students }\end{array}$ \\
\hline $\begin{array}{l}\text { Teacher's stress } \\
\text { inventory [TSI] [10] }\end{array}$ & $\begin{array}{l}\text { Translation and } \\
\text { adaptation }\end{array}$ & $\begin{array}{l}\text { Original TSI by } \\
\text { Fimian (1984) }\end{array}$ & $\begin{array}{l}2003 \text { (120) } \\
\text { Rawalpindi, Islamabad } \\
\text { and Chakwal. }\end{array}$ & - & Teachers only \\
\hline $\begin{array}{l}\text { Aga Khan } \\
\text { University Anxiety } \\
\text { and Depression } \\
\text { Scale } \\
\text { [AKUADS] } \\
\text { [3] }\end{array}$ & $\begin{array}{l}\text { Development and } \\
\text { validation }\end{array}$ & $\begin{array}{l}\text { Psychiatric } \\
\text { evaluation based } \\
\text { on DSM-IV criteria }\end{array}$ & $\begin{array}{l}2005(200) \\
\text { Hyderabad }\end{array}$ & $\begin{array}{l}\text { ROC area under } \\
\text { the curve }=0.73 \\
\text { Cronbach's } \\
a=0.87\end{array}$ & $\begin{array}{l}\text { Pregnant women } \\
\text { only }\end{array}$ \\
\hline $\begin{array}{l}\text { How do I feel } \\
\text { questionnaire [11] }\end{array}$ & $\begin{array}{l}\text { Translation and } \\
\text { validation }\end{array}$ & $\begin{array}{l}\text { Psychiatric } \\
\text { evaluation based } \\
\text { on DSM-IV criteria }\end{array}$ & $\begin{array}{l}2005 \text { (200) } \\
\text { Hyderabad }\end{array}$ & $\begin{array}{l}\text { ROC area under } \\
\text { the curve }=0.74 \\
\text { Cronbach's } \\
a=0.92\end{array}$ & $\begin{array}{l}\text { Pregnant women } \\
\text { only }\end{array}$ \\
\hline $\begin{array}{l}\text { The Pakistan } \\
\text { Anxiety and } \\
\text { Depression Scale } \\
\text { [PADQ] [12] }\end{array}$ & $\begin{array}{l}\text { Development and } \\
\text { validation }\end{array}$ & $\begin{array}{l}\text { Psychiatric } \\
\text { evaluation based } \\
\text { on DSM-IV }\end{array}$ & $\begin{array}{l}2005 \text { (330) } \\
\text { Lahore and Peshawar }\end{array}$ & $\begin{array}{l}\text { Sensitivity }=91 \% \\
\text { Specificity }=94 \% \\
\text { Cronbach's } \\
a=0.92\end{array}$ & $\begin{array}{l}\text { In-patient and } \\
\text { outpatient } \\
\text { psychiatry } \\
\text { patients. }\end{array}$ \\
\hline $\begin{array}{l}\text { Personal Health } \\
\text { Questionnaire } \\
\text { [PHQ] [13] }\end{array}$ & $\begin{array}{l}\text { Translation and } \\
\text { validation in } \\
\text { community } \\
\text { setting }\end{array}$ & $\begin{array}{l}\text { Computer } \\
\text { mediated } \\
\text { interviews based } \\
\text { on Psychiatric } \\
\text { Assessment } \\
\text { Schedule }\end{array}$ & $\begin{array}{l}2006(267) \\
\text { Islamabad }\end{array}$ & $\begin{array}{l}\text { Sensitivity }=78.9 \% \\
\text { Specificity }=85.2 \%\end{array}$ & $\begin{array}{l}\text { Validated for the } \\
\text { construct of } \\
\text { depression only }\end{array}$ \\
\hline $\begin{array}{l}\text { Self-Reporting } \\
\text { Questionnaire } \\
\text { [SRQ] [13] }\end{array}$ & $\begin{array}{l}\text { Translation and } \\
\text { validation in } \\
\text { community } \\
\text { setting }\end{array}$ & $\begin{array}{l}\text { Psychiatric } \\
\text { Assessment } \\
\text { Schedule (PAS) }\end{array}$ & $\begin{array}{l}2006(267) \\
\text { Islamabad }\end{array}$ & $\begin{array}{l}\text { Sensitivity }=93.1 \% \\
\text { Specificity }=80.8 \%\end{array}$ & $\begin{array}{l}\text { Validated for the } \\
\text { construct of } \\
\text { depression only }\end{array}$ \\
\hline $\begin{array}{l}\text { A-Z Stress Scale } \\
{[14]}\end{array}$ & $\begin{array}{l}\text { Development and } \\
\text { validation }\end{array}$ & $\begin{array}{l}\text { Centre for } \\
\text { Epidemiological } \\
\text { Studies- } \\
\text { Depression Scale } \\
\text { (CES-D) }\end{array}$ & $\begin{array}{l}2009(421) \\
\text { Karachi }\end{array}$ & $\begin{array}{l}\text { Correlation } \\
\text { coefficient } r=0.56 \\
\text { Cronbach's } \\
a=0.82 \\
\text { (one week) }\end{array}$ & $\begin{array}{l}\text { Pregnant women } \\
\text { only }\end{array}$ \\
\hline $\begin{array}{l}\text { Depression Scale } \\
\text { for Adolescent } \\
\text { Schoolgirls [DSAG] } \\
\text { [15] }\end{array}$ & $\begin{array}{l}\text { Development and } \\
\text { validation }\end{array}$ & $\begin{array}{l}\text { Children } \\
\text { Depression } \\
\text { Inventory (CDI) by } \\
\text { Kovacs (2007) }\end{array}$ & $\begin{array}{l}2010(587) \\
\text { Lahore }\end{array}$ & $\begin{array}{l}\text { Correlation } \\
\text { coefficient } r=0.68 \\
\text { Cronbach's } \\
a=0.88\end{array}$ & $\begin{array}{l}\text { Adolescent } \\
\text { schoolgirls }\end{array}$ \\
\hline $\begin{array}{l}\text { School Children } \\
\text { Problem Scale } \\
\text { [SCPS] [16] }\end{array}$ & $\begin{array}{l}\text { Development and } \\
\text { validation }\end{array}$ & $\begin{array}{l}\text { Youth Self Report } \\
\text { (YSR) }\end{array}$ & $\begin{array}{l}2011 \text { (853) } \\
\text { Lahore }\end{array}$ & $\begin{array}{l}\text { Correlation } \\
\text { coefficient } r=0.7 \\
\text { Cronbach's } \\
a=0.79 \\
\text { (one week) }\end{array}$ & $\begin{array}{l}\text { School children } \\
\text { only (8th - 10th } \\
\text { graders) }\end{array}$ \\
\hline $\begin{array}{l}\text { Daily Stressor } \\
\text { Scale [DSS] [25] }\end{array}$ & $\begin{array}{l}\text { Development and } \\
\text { validation }\end{array}$ & $\begin{array}{l}\text { Perceived Stress } \\
\text { Scale (PSS) by } \\
\text { Cohen (1983) }\end{array}$ & $\begin{array}{l}2012(264) \\
\text { Pakistan }\end{array}$ & $\begin{array}{l}\text { Correlation } \\
\text { coefficient } r=0.46\end{array}$ & $\begin{array}{l}\text { University } \\
\text { teachers }\end{array}$ \\
\hline
\end{tabular}

community level. Respondents were purposefully identified based on their willingness to give us an extended length of time and to ensure participation of a diverse population such as representativeness of both males and females and of different sociocultural backgrounds. Participants were approached face to face and were informed about the researcher's credentials, personal goals and the purpose of the study while obtaining informed consent.
AA conducted all the interviews; she is a qualified nurse and has training experience in qualitative research methods courses as an academic program. In addition she is a Clinical Research Fellow and Masters in Epidemiology and Biostatistics.

From initial recruitment, we continued to interview participants until same stressful events were being reported and no new stressful event was discussed with the interviewer. Sample size was based on the data 


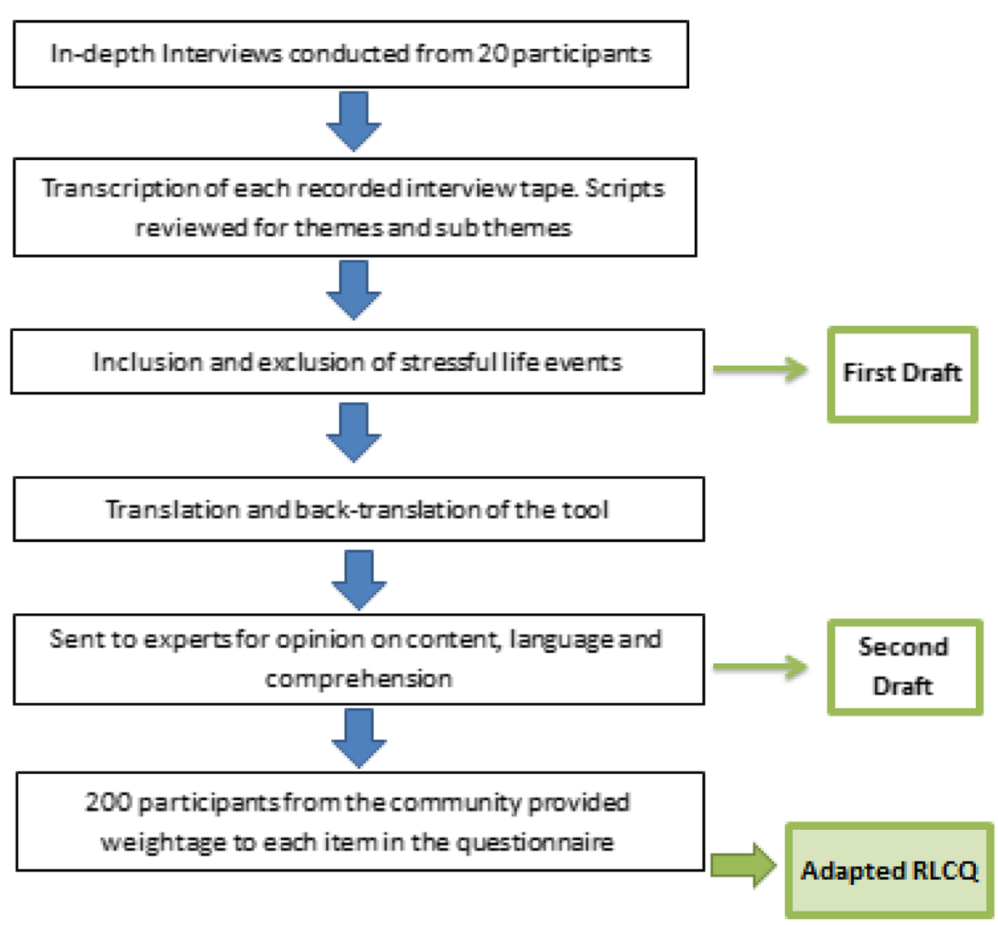

Fig. 1 Study Flow Diagram

saturation. We continued to interview participants until 20 participants were interviewed and theme saturation was achieved. The interviews were conducted in separate rooms that were identified at each outpatient clinic. To ensure privacy of the participants, entry into the room was restricted to the interviewer and the participant only. People accompanying participants were accommodated in the waiting area of the clinic. A semi-structured interview guide was prepared for these interviews exploring stress phenomenon and inquiring about life events that predisposes participants to stress with open ended questions and appropriate prompts. This was pretested in the outpatient clinics where actual sample was to be conducted. Also, the original RLCQ was shared with the participants towards the end of the interview to reflect at the listed stressors. They were encouraged to express their views over events they thought were not stressful within the context of Pakistani community which were later incorporated in the first draft. Interviews were conducted once only and participants were encouraged to share with us as much as possible with the help of prompts. Audio recording was performed. Patient identity was kept confidential. Field notes were taken during interview and were reviewed with transcription. While concluding each interview, major points shared during the interview were summarized with the participants.

Transcriptions were done of these interviews and scripts were reviewed by the first authors along with its coding. These were discussed with all the research team who reached consensus with regards to data saturation and which culminated our first draft of the adapted RLCQ (Additional file 1). It comprised of newly identified stressful events along with removal of those that were perceived as not stressful. Translation and back translation of the tool was done to ensure face validity. Later, it was sent to experts for review which included a sociologist, a psychologist and two individuals belonging to the public health domain. The experts were identified based on formal completion of post-graduate education along with greater than 10 years of local experience in the field of stress and community work in the area. Qualitative research experts also reviewed the content and layout of the work. They provided written feedback on the language, understanding, content representativeness with respect to the construct and duration for completion which culminated our second draft. This draft was pre-tested in the communities which we planned to approach for scoring items on the questionnaire (Fig. 1).

\section{Step II: Scoring of items on adapted RLCQ by communities}

For each item on the adapted RLCQ, we needed a score that could represent the magnitude of stress perception numerically. Hence for scoring, we required 200 participants. The sample size was based on the recommendation by Kline as a requirement of principal component analysis that we were to apply for tool development [20]. 


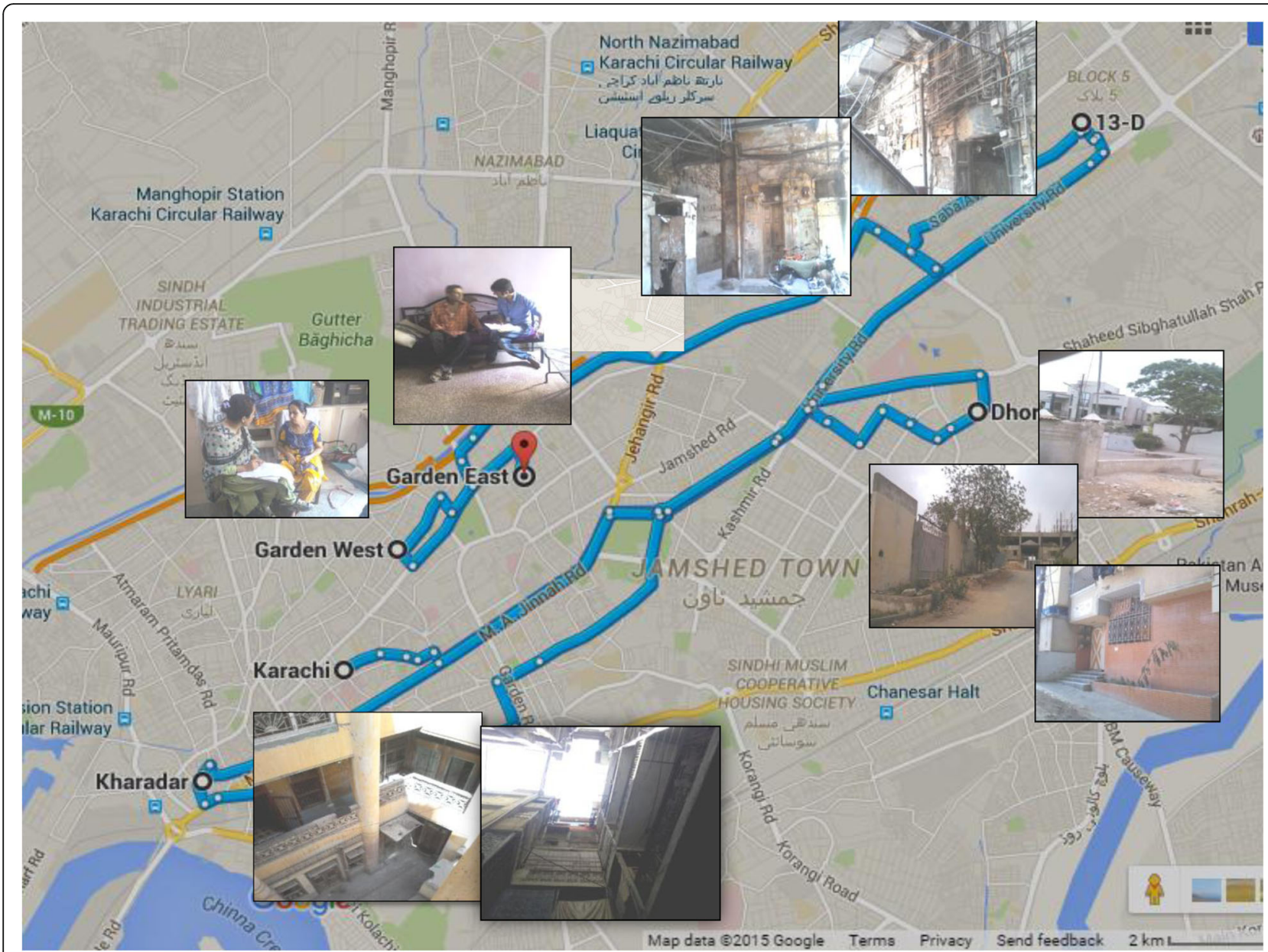

Fig. 2 Community sites - Garden, Kharadar, Gulshan and Dhorajee

As we had 83 events on the adapted RLCQ, item to responders' ratio of 1:2 was suggested.

Systematic random sampling technique was used in each selected area. Households were selected based on the $\mathrm{k}^{\text {th }}$ number that was determined from estimated population of these areas. As these communities were equally dense, we chose every eighth house based on $\mathrm{k}^{\text {th }}$ number. One participant was chosen at random from each household fulfilling the entry criteria. These participants were not the same from whom in-depth interviews were conducted.

Participants were asked to rate each life event in the draft on a continuum of 0 to 100 where 0 represented no stress and 100 represented maximum stress that can be tolerated.

\section{Human subjects approvals and registration}

Ethical approval was sought from Ethical Review Committee, Aga Khan University which granted permission on 14th October 2014 with study registration ID as 3235-CHS-ERC-14. The study was registered as an observational study at Clinicaltrials.gov with the study ID NCT02356263.

\section{Statistical analysis plan}

For statistical analysis, STATA version 12 was used. We calculated means, medians and modes for the scores of all the events in the questionnaire. We kept mean as the score of an event. In case of events in which rated mean was different from median with \pm 5 points, we kept median as the score of those events. We applied exploratory factor analysis on the entire data so as to classify events in the adapted questionnaire into categories reflecting similar notion.

\section{Results}

\section{Step I results: Qualitative stressful life events: Themes identified}

We interviewed 20 participants, equal gender with equal number of men and women with an average age of 48 years $(\mathrm{SD}=5.6$ years). 12 individuals refused to participate as they had time constraints. However, those 
who gave consent continued the entire interview and there were no drop outs. The mean duration of these interviews was of $57 \mathrm{~min}$. Transcriptions were read multiple times by the first authors and were verified for correctness with the audio recordings. Notes were made over experiences shared by the participants. Content analysis of the data began by identifying key words and phrases from the text and segregating it into smaller units. Upon further readings, the units indicating similar experiences were coded in all the transcripts. These codes were discussed by the research team and with agreement of all, were categorized and grouped into sub-themes. Out of these sub-themes, broader themes were extracted that became the newly identified stressful life events which with final consensus of the research team were included in the adapted RLCQ. Table 2 describes the sub-themes and themes that were derived from the data along with participant's quotes. Transcription was typed in MS word 2010. Extraction of codes and revision were first done manually then updated electronically. These themes are in congruence with actual data. The qualitative interviews conducted from participants revealed a range of stressful events that stem from the socio-political environment within Pakistan. These events described difficulties that residents face in their daily lives such as lack of power, fuel and sanitation. In addition, social beliefs and values were causes of chronic stress such as such as having an unmarried middle aged daughter, prejudices of bearing a male child, harassment in public and lack of women empowerment within homes and at work. There were references to the political environment such as state sponsored brutality, missing job opportunity because of nepotism and lack of meritocracy, extortion of money by force and suicide bombings (Table 2).

Conversely, there was unanimous consensus among the participants to remove events such as promotion, lesser work responsibility, vacation, major increase in income, moderate purchase, major dental work, birth of a grandchild and major personal achievement. These events were regarded as "fortunate events" rather than stressful. Most participants felt that they did not have a place in the stressful life event category.

\section{Step II results: Categorization of events of varying stress severity by communities}

The original categories of the RLCQ focus on family, personal, social, health and financial circumstances of life. It did not have a structure to take these newly identified events into their existing framework as it has no representative category that could classify environment related life stressors. We tried to do an exploratory factor analysis where each event was dealt independently so that new possible categories could be formed for the structure of adapted RLCQ. Keeping a cut-off value of $\geq 1$ of Eigen values as selection criteria of factors, we assessed 10 emerging possibilities in which all the events on the adapted draft had been grouped.

When all the events were arranged into their respective categories, they appeared to have lost the meaning of the stressors as a group because they were non-representative with each other and seemed jumbled up. Hence, we decided to place all the events in the same order of groups as it was in the original RLCQ and introduced another group of stressors having all the new events calling it as "environmental factors" (Table 3).

Out of 83, 23 events required median as event weightage whereas for others, means were closer to the median and hence we kept mean as their event weightage. At the end of this phase, we had our adapted RLCQ which was enriched with contextually relevant stressors through qualitative exploration, content validation via experts and face validity. Also, it depicts community's perception upon severity of each event as the scores for the adapted tool were derived by community participation.

\section{Discussion}

The adapted RLCQ enumerates stressful life events that reflect stressors within an urban population of a multiethnic city in a Low-Middle Income Country (LMIC). These events influence daily life of individuals residing in these countries such as lack of basic living facilities, gender inequality, harassment and lack of social security and were different from the original RLCQ, hence a new category of 'environment' was formed to incorporate these events. Moreover, the relevant communities were involved in the entire process of rating which clarified the impact of these events in people's life.

Stressful life events for adults living in Pakistan differ from developed countries because of poverty, lawlessness and political instability. The events of our adapted RLCQ are in congruence with those that were concluded in other adaptation studies of low middle income countries [21]. It depicts that theft, lack of basic living facilities, natural disasters, social discrimination and an insecure living environment prevails in these countries and hence has been included by them in the list $[22,23]$. However, being a victim of suicide bombing and state sponsored brutalities has never been highlighted in any of the studies prior to our findings. These events are important mediators of population mental health and should be part of the systematic review of health within LMIC settings.

The adapted RLCQ is a simple tool and can be administered by community health workers. It was derived from qualitative exploration following COREQ guidelines that ensure rigor within this methodology. The adapted RLCQ mirrors stressful events in context of 
Table 2 Themes and sub-themes describing stressful life events of urban adult population of Karachi

\begin{tabular}{ll}
\hline Themes & Sub-themes \\
\hline $\begin{array}{l}\text { Subjected to harassment in } \\
\text { public }\end{array}$ & $\begin{array}{l}\text { - Hooting by boys in marketplaces. } \\
\text { - Touching young females while crossing by. } \\
\text { - Bikers speeding up towards ladies at bus stand. }\end{array}$ \\
& \\
Male child preference & - Giving boys freedom to go anywhere and come at \\
& whatever time without questioning at home. \\
& - Liberty to boys to go out alone. \\
& Females are instructed to speak in lower voices \\
& which males aren't.
\end{tabular}

Unmarried middle aged daughter

Being a mother of an infant(s)

Being a mother of an infant(s)

Robbed/theft

Missed an opportunity because of nepotism

Extortion or illegal demands of money by force

Lack of respect to females/ lack of empowerment

Being a victim of state sponsored brutality
- Due to cultural issues, worried about letting a daughter marry who is above 25 years of age.

- Future insecurities about unmarried daughter while having daughter in law at home.

- Monetary support for unmarried daughters while parents are retired.

- Wondering about security issues of unmarried daughters of elderly parents after them.

- Due to cultural issues, worried about letting a daughter marry who is above 25 years of age.

- Future insecurities about unmarried daughter while having daughter in law at home.

- Monetary support for unmarried daughters while parents are retired.

- Wondering about security issues of unmarried daughters of elderly parents after them.

- Difficulty in maintaining work and home responsibilities with infant

- Disturbed routine of self and added responsibilities of the infant.

- Focus of family is the infant and mother feels neglected.

- Mobile snatching on the streets.

- Robbery at home and in banks.

- Theft in public transportation such as buses and threats to kill if not surrendered.

- Despite of capability, unable to get at a good job.

- Individuals without qualification get selected because of political backing.

- Easier for rich to bribe selection committee.

- To run a business safely and personal security, giving away money to political parties by force.

- "Bhattas/Chanda" as locally pronounced to be given to local influential people in an area for various unrelated activities

- Not taking input from females in important decisions of the family or their own life such as marriage.

- Not allowing females to attain employment or even if allowed, not outside the area of their residence.

- To bear maltreatment by males in virtue of good character of a female.

- Due to tussles between political/influential groups, common people being abused, beaten or even killed.
Participant's Quotes

- P [1]: "It is very traumatizing when one realizes that a

man has touched you in public, deliberately"

- P [16]: "Bikers scare us leaving unforgettable memories when they come at full speed and cross by us in public and hooting remarks on us"

- P [5]: "At home, I am usually asked where I was if I stay out of the home after sunset for giving tuitions, but never from my brother. It's a persistent stress and threat to individuality"

- P [7]: "I can't scream even when I am in pain. I have been taught since childhood 'girls don't shout'. I feel inferior"

- P [17]: "I feel anxious thinking about what my daughter's life will be if we aren't alive. She's already 25. I have become obsessive in thinking how can I find my daughter a match"

- P [1]: "In our society, it is difficult for lonely girls to survive. Parents retire, brothers marry and sister in laws are unpredictable. If one won't marry, one will have to be dependent on their mood and privacy to talk to brothers"

- P [17]: "I feel anxious thinking about what my daughter's life will be if we aren't alive. She's already 25. I have become obsessive in thinking how can I find my daughter a match"

- P [1]: "In our society, it is difficult for lonely girls to survive. Parents retire, brothers marry and sister in laws are unpredictable. If one won't marry, one will have to be dependent on their mood and privacy to talk to brothers"

- P [9]: "Life with children is tough for working women. We have to meet expectations everywhere be it home, office, neighborhood"

- P [11]: "I stay awake all night. I can't have rest in the day too as I have a lot of things to handle singlehandedly. My husband thinks it is only a mother's responsibility to take care of the kid. He is only for breadwinning"

- P [2]: "I never use my mobile phone when I am in a less busy street. I will be caught by snatchers"

- P [8]: "Even in public bus, I had been a victim twice where all passengers were robbed. I had great loss from that and have stopped using buses"

- P [10]: "Despite of a degree, I have lowpaid job. It is definitely suicidal for a graduate young man to be a driver, like me"

- P [13]: "I have been a brilliant student, but a rich man's son was more of a value than my talent"

- P [15]: "Making more money lawfully is also a trouble in this country. One has to give away it at once when demanded by influential people"

- P [17]: "Nearly a quarter of my husband's salary goes in chandas (donation) which political party people collect by force in the name of good."

- $P$ [3]: "I am never involved in making decisions for the family despite of being eldest because I am a female" - P [7]: "When my husband bullies, I can't even speak about it. It is not understood good in the society. A women's character is her silence"

- P [2]: "My father had had an accident when two local groups were fighting in public with each other. He has a disability and cannot recover" 
Table 2 Themes and sub-themes describing stressful life events of urban adult population of Karachi (Continued)

Lack of power supplies (electricity)

Lack of fuel supplies (natura gas at home, CNG, petrol)

Insecure living environment

Lack of water and sanitation facilities

Received a threat from an influential person

Destructions due to natural disasters

Social stigma pertinent to middle aged unmarried females

Direct experience of suicide bombing

Get to know about Suicide Bombing event on news, neighbors, city
- Unpredicted load shedding.

- Major electrical failure by electricity providing companies.

- Illegal connections built by others and lack of supply or increased cost to those who pay legally.

- Limited supply of CNG in week i.e. only 3-4 days. This implies long queue when supplied.

- Difficulties faced by daily wagers of public transport such as rickshaw and taxis.

- Low pressure or no natural gas for cooking which implies maintaining every day routine difficult.

- Abduction for money.

- Shot in robbery.

- Bomb blast incidences.

- Joblessness despite of qualification.

- Waste collection and disposal practices are poor in general.

- Overflowing drains and open stagnant water creating problems for passers-by as well as to local residents.

- Threat to life or harm to family in lieu of not doing their work or not giving them money.

- Due to floods each year, a great monetary loss is faced by the sufferers.

- Improper preparation of flood plan causes many lives to be lost including cattle which are a source of living for some.

- Society considers that unmarried females do not have a good character hence no one marries them.

- Stigma with respect to inability to give dowry.

- Bomb blasts are traumatizing event both physically and psychologically.

- Disabled victims bear the burden of event for lifetime.

- Damage of personal property and loss of loved ones in bombing.

- Stress produced by repeated coverage of the event on the television.

- Fear of future of children and loved ones.

- Feeling hopeless for betterment of country's condition.
- P [15]: "In Karachi, electricity is a luxury. Despite paying high amount of bills, we do not get electricity for $9 h !^{n}$

- P [5]: "Electrical failure follows no routine. It becomes worst in the exam days. Utility bills are high yet seldom supply. Illegal connections supply you electricity unconditionally at all times"

- P [10]: "When CNG stations are closed, passengers are lost because of lack of fuel. When stations open or partially available, it takes ages to get your turn and grab it"

- P [11]: "It becomes impossible to cook food for the family in such low pressure. What could be done in half an hour takes around four hours and sometimes nothing at all!"

- P [15]: "I am alive today. Don't know whether I will be kidnapped or shot dead like my friend was, just for money"

- $P$ [13]: "There is no future in Pakistan. No jobs, no security, no laws, no ethics. The world is way organized and humanitarian than it is!"

- P [14]: "There is mixed water supply (sewerage and fresh water) in our area over an year. We complained but no use. Our kids become sick every other day"

- P [12]: "In rainy season, the city becomes a mess. Drains are open, roads have loads of puddles and no one cares about it!"

- P [4]: "It has become tougher to stay safe these days. You are followed, inquired about and then threatened for well-being of family. Giving money is better than threats and torture"

- P [12]: "There is no concept of urban planning. We make no dams despite of floods every year and later cry for a drop of clean water"

- P [5]: "In our area, we expect our river to flood each year. Government makes promises which they do not keep. We lose our cattle, homes, farms and then next year thrive to build it again"

- P [20]: "Society and relatives think I don't have a good character just because I didn't get married even by $40 s^{\prime \prime}$

- $P$ [3]: "My parents started gathering things to be given to me as dowry but those who come to choose me never find it enough"

- P [4]: "I had witnessed a blast myself. I was praying and all of a sudden couldn't hear anything. I was all numbed. When I recovered, all I could see was people over people. I could smell blood and flesh. To my living memory, I can't ever forget that!"

- P [9]: "I have left watching news. All it covers is disturbing. When I hear about a blast on the TV, instantly get horrified. I rush to my phone and start calling to my family members outside just to know they are safe!"

- P [2]: "It is worst to hear that a loved one has passed away in a bomb blast and when he's so young and only one to support family"
LMICs urban population. Through community participation during rating of events exercise, we were able to understand better the importance and impact of one life event as compared to other life events for e.g. death of a family member was given a higher score as compared to death of a close friend.

There are other approaches to measuring stressful life events such as the Brown and Harris approach where 
Table 3 Final draft of RLCQ

\begin{tabular}{|c|c|c|c|c|c|c|c|}
\hline S. \# & Work & LCU & My LCU & S. \# & Home and family & LCU & My LCU \\
\hline 1. & $\begin{array}{l}\text { Unwilling change to a new } \\
\text { type of work }\end{array}$ & 54 & & 1. & $\begin{array}{l}\text { Shifting within same town or } \\
\text { city }\end{array}$ & 64 & \\
\hline 2. & $\begin{array}{l}\text { Unwilling change in your } \\
\text { work hours or conditions }\end{array}$ & 54 & & 2. & $\begin{array}{l}\text { Shifting to different town, } \\
\text { city or province }\end{array}$ & 75 & \\
\hline 3. & More work responsibilities & 65 & & 3. & $\begin{array}{l}\text { Major change in living } \\
\text { conditions }\end{array}$ & 61 & \\
\hline 4. & A demotion & 69 & & 4. & $\begin{array}{l}\text { Unwilling change in family } \\
\text { get-togethers }\end{array}$ & 55 & \\
\hline 5. & A transfer & 62 & & 5. & $\begin{array}{l}\text { Major change in health or } \\
\text { behavior of a family member }\end{array}$ & 70 & \\
\hline 6. & Trouble with your boss & 57 & & 6. & Marriage & 64 & \\
\hline 7. & Trouble with co-workers & 50 & & 7. & Pregnancy & 67 & \\
\hline 8. & Other work related difficulties & 53 & & 8. & Miscarriage or abortion & 77 & \\
\hline 9. & Major business readjustment & 64 & & 9. & Birth of a child & 59 & \\
\hline 10. & Retirement & 80 & & 10. & Adoption of a child & 62 & \\
\hline 11. & Laid off & 62 & & 11. & Relative moves in with you & 64 & \\
\hline 12. & Fired & 90 & & 12. & Spouse begins or stops work & 62 & \\
\hline \multirow[t]{2}{*}{13.} & Took a course to help work & 52 & & 13. & $\begin{array}{l}\text { Child leaves home for } \\
\text { marriage }\end{array}$ & 79 & \\
\hline & Health & LCU & My LCU & 14. & $\begin{array}{l}\text { Child leaves home for other } \\
\text { reasons }\end{array}$ & 63 & \\
\hline 1. & $\begin{array}{l}\text { An illness or injury that kept } \\
\text { you in bed for more than a } \\
\text { week or sent you to hosp. }\end{array}$ & 72 & & 15. & Arguments with spouse & 64 & \\
\hline 2. & $\begin{array}{l}\text { An illness or injury that was } \\
\text { less serious than above }\end{array}$ & 47 & & 16. & Problems with relatives/in-laws & 50 & \\
\hline 3. & $\begin{array}{l}\text { Major change in eating } \\
\text { habits }\end{array}$ & 46 & & 17. & Parent's divorce & 100 & \\
\hline 4. & $\begin{array}{l}\text { Major change in sleeping } \\
\text { habits }\end{array}$ & 49 & & 18. & A parent remarries & 90 & \\
\hline \multirow[t]{2}{*}{5.} & $\begin{array}{l}\text { Major change in your usual } \\
\text { type or amount of recreation }\end{array}$ & 44 & & 19. & $\begin{array}{l}\text { Separation from spouse due } \\
\text { to work }\end{array}$ & 70 & \\
\hline & Personal and social & LCU & My LCU & 20. & $\begin{array}{l}\text { Separation from spouse due } \\
\text { to marital difficulties }\end{array}$ & 88 & \\
\hline 1. & Change in personal habits & 46 & & 21. & Divorce & 100 & \\
\hline 2. & Change in school or college & 53 & & 22. & Death of a spouse & 100 & \\
\hline 3. & Change in political beliefs & 48 & & 23. & Death of a child & 100 & \\
\hline 4. & Change in religious beliefs & 75 & & 24. & Death of a parent & 100 & \\
\hline 5. & Change in social activities & 51 & & 25. & Death of a sibling & 76 & \\
\hline 6. & $\begin{array}{l}\text { New, close personal } \\
\text { relationship }\end{array}$ & 51 & & 26. & Being an elder son & 77 & \\
\hline 7. & Engagement & 59 & & 27. & $\begin{array}{l}\text { Having a mentally challenged } \\
\text { person in the family }\end{array}$ & 72 & \\
\hline 8. & $\begin{array}{l}\text { Girl friend or boyfriend } \\
\text { problems }\end{array}$ & 70 & & 28. & $\begin{array}{l}\text { Dealing with a child's chronic } \\
\text { illnesses }\end{array}$ & 77 & \\
\hline 9. & Sexual difficulties & 58 & & & Environmental & LCU & My LCU \\
\hline 10. & An accident & 80 & & 1. & Robbed/theft & 90 & \\
\hline 11. & $\begin{array}{l}\text { Falling out of a close } \\
\text { personal relationship }\end{array}$ & 65 & & 2. & $\begin{array}{l}\text { Missed an opportunity } \\
\text { because of nepotism }\end{array}$ & 75 & \\
\hline
\end{tabular}


Table 3 Final draft of RLCQ (Continued)

\begin{tabular}{|c|c|c|c|c|c|c|}
\hline 12. & Minor violation of law & 52 & & 3. & $\begin{array}{l}\text { Extortion or illegal demands } \\
\text { of money by force }\end{array}$ & 90 \\
\hline 13. & Being held in jail & 100 & & 4. & $\begin{array}{l}\text { Lack of respect to females/ } \\
\text { lack of empowerment }\end{array}$ & 74 \\
\hline 14. & Death of a close friend & 68 & & 5. & $\begin{array}{l}\text { Being a victim of state } \\
\text { sponsored brutality }\end{array}$ & 80 \\
\hline 15. & $\begin{array}{l}\text { Subjected to harassment in } \\
\text { public }\end{array}$ & 71 & & 6. & $\begin{array}{l}\text { Lack of power supplies } \\
\text { (electricity) }\end{array}$ & 78 \\
\hline 16. & Male child preference & 62 & & 7. & $\begin{array}{l}\text { Lack of fuel supplies (natural } \\
\text { gas at home, CNG, petrol) }\end{array}$ & 76 \\
\hline 17. & $\begin{array}{l}\text { Unmarried middle aged } \\
\text { daughter }\end{array}$ & 76 & & 8. & Insecure living environment & 76 \\
\hline \multirow[t]{2}{*}{18.} & $\begin{array}{l}\text { Being a mother of an } \\
\text { infant(s) }\end{array}$ & 60 & & 9. & $\begin{array}{l}\text { Lack of water and sanitation } \\
\text { facilities }\end{array}$ & 80 \\
\hline & Financial & LCU & My LCU & 10. & $\begin{array}{l}\text { Received a threat from an } \\
\text { influential person }\end{array}$ & 90 \\
\hline 1. & Major loss of income & 76 & & 11. & $\begin{array}{l}\text { Destructions due to natural } \\
\text { disasters }\end{array}$ & 90 \\
\hline 2. & $\begin{array}{l}\text { Investment and/or credit } \\
\text { difficulties }\end{array}$ & 74 & & 12. & $\begin{array}{l}\text { Social stigma pertinent to } \\
\text { middle aged unmarried } \\
\text { females }\end{array}$ & 85 \\
\hline 3. & $\begin{array}{l}\text { Loss/damage to personal } \\
\text { property }\end{array}$ & 90 & & 13. & $\begin{array}{l}\text { Direct experience of suicide } \\
\text { bombing }\end{array}$ & 100 \\
\hline 4. & Major purchase & 63 & & 14. & $\begin{array}{l}\text { Get to know about Suicide } \\
\text { Bombing event on news, city, } \\
\text { neighbors }\end{array}$ & 76 \\
\hline 5. & $\begin{array}{l}\text { Foreclosure or mortgage or } \\
\text { loan }\end{array}$ & 80 & & & Total & \\
\hline
\end{tabular}

contextuality of the event is discussed in detail and gives further insight [24]. However, as an initial approach, without identifying even our basic life events, Brown and Harris's contextual approach becomes challenging as it requires great deal of expertise and time to conduct such interviews with each individual where researchers could rate the severity of stressors without being influenced with the nature and timeliness of the circumstances being explored [24]. Furthermore, considering the Pakistani context where access to community mental health facilities is difficult, identifying stress using this approach in such resource scarce setting raises concerns to its applicability [24].

The aim of the current study was to develop a community based screening tool (adapted RLCQ) rather than a sophisticated tool to measure stress in the context of Pakistani population. We have a rich resource of community health workers that is now beginning to be trained for mental health work at very basic units. From the sustainability point of view, it is much easier for community health workers to screen and identify high risk individuals based on this adapted RLCQ that consumes less time and professional expertise.

This adaptation study has certain limitations. As we interviewed participants they may have more readily shared events that they feel less stigmatized to talk about from a socio-cultural perspective. This takes into account listing stressors that are socio-culturally acceptable to discuss openly. For events that are stigmatized, such as rape, drug abuse or other such events that are social taboos, stigma would have introduced a reporting bias. Having acknowledged that, we still have noted serious issues of extortion, suicide bombing, and harassment that were reported in this study. For any country with socio-political instability, it is highly likely that new stressful events would occur in a short time frame that would affect consistency of the tool when used over longer time frames to quantify stress. Minor themes have not been discussed in this paper, as our aim of the qualitative phase was to explore stressors that reflect Pakistani population majorly so that we could include these events in our adapted tool. The applicability of the adapted RLCQ to an overseas Pakistani community becomes limited with respect to the change in environmental circumstances. Essential sociocultural values that are nurtured at early stages of life of every individual may still be applicable to Pakistanis residing outside the country however, environmental and financial stressors may differ. For instance they may face social discrimination while they may not encounter problems due to 
unavailability of water or electricity. Overall, the applicability of adapted RLCQ depends on the nature of the research as it becomes limited with respect to the change in environmental circumstances Future research is planned to explore the validity of the adapted RLCQ in the study population and may additionally explore resilience and resilience boosting strategies at the community level.

\section{Conclusions}

Mental health in Pakistan needs integration in the existing infrastructure. This relevant tool can be utilized effectively in screening of individuals at the community level where effective interventions could be planned and performed for high risk groups. Initiatives such as identifying social support groups, behavioral therapies and resilience boosting strategies could help communities draw strength for coping.

\section{Additional file}

Additional file 1: First Draft of the Adapted RLCQ. (DOCX 19 kb)

\section{Abbreviations \\ AKUH: Aga Khan University Hospital; COREQ: Consolidated Criteria for Reporting Qualitative Research; LMIC: Low-Middle Income Countries; RLCQ: Recent Life Changes Questionnaire; SRRS: Social Readjustment and Rating Scale; WHO: World Health Organization}

\section{Acknowledgements \\ We would like to acknowledge the patience, kindness, time and cooperation of all participants and their families who contributed to this study. We are always inspired by them and respect their courage. We would like to acknowledge Professor Richard Rahe who had given us permission and guidance. Also, we are extremely thankful to our all experts on content validation committee for giving their expert opinion.}

\section{Funding}

The study is funded by Award Number 5D43TW008660-05 from the Fogarty International Center and the National Institute of Neurologic Disorders and Stroke of the National Institutes of Health, USA. The funding body has no input in the design of the study and collection, analysis, and interpretation of data.

\section{Availability of data and materials}

The dataset that represents the entirety of this qualitative study is reported completely in Tables 2 and 3 and is accessible to all readers. Detailed interview transcripts are not publically available due to the sensitive nature of the interview and the materials shared by the participants.

\section{Authors' contributions}

AKK conceived the study design, wrote and critically reviewed the manuscript jointly with AA. AA directly overlooked all aspects of study design, logistics, analysis, and follow up and wrote the manuscript with AKK. IA assisted for statistical design. SS and AK reviewed the study for overall quality and facilitated qualitative design and review of data. MA assisted for community activities and data collection. All authors have reviewed and contributed intellectually to this manuscript. All authors read and approved the final manuscript.

\section{Authors' information}

The authors are a diverse team of scientists, research nursing, biomedical engineers and innovators that work together to implement vascular health solutions in challenging LMIC settings. This work is important as it provides the basis for a tool to screen for stress in a public health setting which is an emerging risk factor for strokes and heart attacks.

\section{Competing interests}

The authors declare that they have no competing interests. The funders had no role in study design, data collection, analysis, decision to publish, or preparation of the manuscript. The content is solely the responsibility of the authors and does not necessarily represent the official views of the Fogarty International Center, National Institute of Neurologic Disorders and Stroke or the National Institute of Health.

\section{Consent for publication}

All images provided in this manuscript are with due permission and consent of the participants.

\section{Ethics approval and consent to participate}

This study was approved by the Aga Khan University ethical approval committee, with ERC number 3235-CHS-ERC-14. All participants provided written informed consent.

\section{Publisher's Note}

Springer Nature remains neutral with regard to jurisdictional claims in published maps and institutional affiliations.

\section{Author details}

'Stroke Service, The International Cerebrovascular Translational Clinical Research Training Program (Fogarty International Center, National Institutes of Health) and Aga Khan University, Karachi, Pakistan. ${ }^{2}$ Aga Khan University School of Nursing \& Midwifery, Karachi, Pakistan. ${ }^{3}$ Biostatistics and Epidemiology, Department of Community Health Sciences, Aga Khan University, Karachi, Pakistan. ${ }^{4}$ MBBS Program, Jinnah Medical and Dental College, Karachi, Pakistan. ${ }^{5}$ Stroke Service, Department of Medicine, Aga Khan University, Karachi, Pakistan. ${ }^{6}$ Section of Neurology, Department of Medicine, Stroke Fellowship Program, International Cerebrovascular Translational Clinical Research Training Program, Fogarty International Center, National Institute of Neurologic Disorders and Stroke (USA), Aga Khan University, Stadium Road, Karachi 74800, Pakistan.

Received: 13 August 2016 Accepted: 19 April 2017

Published online: 05 May 2017

\section{References}

1. Nevid J. Essentials of psychology: concepts and applications (3rd ed., international ed). Belmont: Wadsworth Cengage learning; 2012.

2. Wagnild G. A review of the resilience scale. J Nurs Meas. 2009;17(2):105-13.

3. Sharpley CF. Neurobiological pathways between chronic stress and depression: dysregulated adaptive mechanisms. Clinical Medicine: Psychiatry. 2009;2:33-45.

4. Kalia M. Assessing the economic impact of stress [mdash] the modern day hidden epidemic. Metabolism. 2002;51(6):49-53.

5. Whiteford HA, Degenhardt L, Rehm J, Baxter AJ, Ferrari AJ, Erskine HE, et al. Global burden of disease attributable to mental and substance use disorders: findings from the Global burden of disease study 2010. Lancet. 2013;382(9904):1575-86

6. Naqvi $H$, Khan MM. Depression in primary care: difficulties and paradoxes. Depression. 2005;55:393-8.

7. Kidwai R. Demographic factors, social problems and material amenities as predictors of psychological distress: a cross-sectional study in Karachi, Pakistan. Soc Psychiatry Psychiatr Epidemiol. 2014;49(1):27-39.

8. Ahmer S, Faruqui RA, Aijaz A. Psychiatric rating scales in Urdu: a systematic review. BMC Psychiatry. 2007;7(1):59.

9. Riaz H, Reza $\mathrm{H}$. The evaluation of an Urdu version of the GHQ-28. Acta Psychiatr Scand. 1998;97(6):427-32.

10. Pervez $S$, Hanif R. Levels and sources of work stress among women school teachers. Pak J Psychol Res. 2003;18(3-4).

11. Karmaliani R, Bann CM, Pirani F, Akhtar S, Bender RH, Goldenberg RL, et al. Diagnostic validity of two instruments for assessing anxiety and depression among pregnant women in Hyderabad, Pakistan. Health Care Women Int. 2007;28(6):556-72.

12. Mumford DB, Ayub M, Karim R, Izhar N, Asif A, Bavington JT. Development and validation of a questionnaire for anxiety and depression in Pakistan. J Affect Disord. 2005;88(2):175-82. 
13. Husain N, Gater R, Tomenson B, Creed F. Comparison of the personal health questionnaire and the self reporting questionnaire in rural Pakistan. J Pak Med Assoc. 2006;56(8):366.

14. Kazi A, Fatmi Z, Hatcher J, Niaz U, Aziz A. Development of a stress scale for pregnant women in the south Asian context: the AZ stress scale. 2009.

15. Naz MA, Siddiqui S. Development of an Indigenous Depression Scale for Adolescent Schoolgirls. Pak J Psychol Res. 2011;25(2).

16. Saleem S, Mahmood Z. Development of a scale for assessing emotional and behavioral problems of school children. Pak J Soc Clin Psychol. 2011;9:73-8.

17. Hobson CJ, Kamen J, Szostek J, Nethercut CM, Tiedmann JW, Wojnarowicz S. Stressful life events: a revision and update of the social readjustment rating scale. Int J Stress Manag. 1998:5(1):1-23.

18. Miller MA, Rahe RH. Life changes scaling for the 1990s. J Psychosom Res. 1997;43(3):279-92

19. Tong A, Sainsbury P, Craig J. Consolidated criteria for reporting qualitative research (COREQ): a 32-item checklist for interviews and focus groups. Int J Qual Health Care. 2007;19(6):349-57.

20. Kline P. An easy guide to factor analysis: Routledge; 2014

21. Ovuga E, Boardman J, Wasserman D. The response inventory for stressful life events (RISLE) II: validation of the 36-item version. Afr Health Sci. 2005; 5(2):145-51.

22. Lund C, Breen A, Flisher AJ, Kakuma R, Corrigall J, Joska JA, et al. Poverty and common mental disorders in low and middle income countries: a systematic review. Soc Sci Med. 2010;71(3):517-28.

23. Das J, Do Q-T, Friedman J, McKenzie D, Scott K. Mental health and poverty in developing countries: revisiting the relationship. Soc Sci Med. 2007:65(3): 467-80.

24. Kessler RC. The effects of stressful life events on depression. 1997.

25. Naseem Z, Khalid R. Daily stressors of University teachers of Pakistan: development and validation of a scale. J Res. 2012;6(1):1-15.

\section{Submit your next manuscript to BioMed Central and we will help you at every step:}

- We accept pre-submission inquiries

- Our selector tool helps you to find the most relevant journal

- We provide round the clock customer support

- Convenient online submission

- Thorough peer review

- Inclusion in PubMed and all major indexing services

- Maximum visibility for your research

Submit your manuscript at www.biomedcentral.com/submit

) Biomed Central 